\title{
四塩化ケイ素を用いたプラズマCVD法による $\mathrm{SiC}$ 薄膜の形成
}

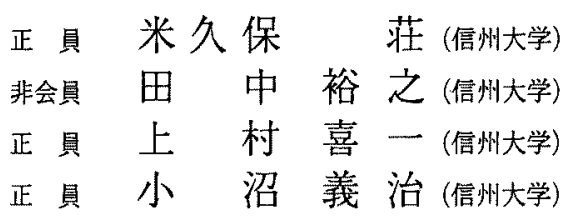

Preparation of SiC Thin Films by Plasma-Enhanced Chemical Vapor Deposition Using Silicon Tetrachloride So Yonekubo, Member, Hiroyuki Tanaka, Non-member, Kiichi Kamimura, Member, Yoshiharu Onuma, Member (Shinsyu University)

The basic properties of silicon carbide thin films prepared by plasma-enhanced chemical vapor deposition using silicon tetrachloride were studied. It was found that the films prepared at the substrate temperature of higher than $700^{\circ} \mathrm{C}$ were polycrystalline, and the grain size of about $20 \mathrm{~nm}$ was obtained for the films prepared at the substrate temperature of $800^{\circ} \mathrm{C}$. The stoichiometric silicon carbide films showed $\mathrm{n}$ type conduction, while the carbon rich silicon carbide films showed $p$ type conduction. Hall mobility and the carrier concentration were about $20 \mathrm{~cm}^{2} / \mathrm{V} \cdot \mathrm{sec}$ and $2 \times 10^{17} \mathrm{~cm}^{-3}$, respectively for the stoichiometric films prepared at the substrate temperature of $800^{\circ} \mathrm{C}$. Thermoelectromotive force of silicon carbide films was measured and thermoelectric power, the sensitivity as sensor, was about $50 \mu \mathrm{V} / \mathrm{deg}$.

キーワード: プラズマCVD, SiC, 四塩化ケイ素, 多結晶薄膜, 熱起電力

\section{1 はじめに}

炭化ケイ素 $(\mathrm{SiC})$ は，半導体材料の中でも禁制带幅が大き いこと, 熱的, 化学的に安定なこと, 高硬度を有すること などのため, 耐熱性電子デバイスとして, また青色発光素 子として注目され研究されている(1)-(6)。

単結晶SiCはその形成に高温を必要としている(7) (11)。し かし，SiCの特質を生かした応用を考える場合，例えば， 耐熱性センサ，耐熱性TFT，ヘテロ接合デバイスなど，用 途によっては必ずしも単結晶を必要とはせず，多結晶 SiC で十分である。多結晶SiCの特徴は，

(1) 単結晶SiCの形成に比べ高温プロセスを必要としない。

(2) アモルファス SiC 薄膜と比較して熱的に安定である。

（3）特殊な設備を必要とせず容易に形成できる。 などである。多結晶 $\mathrm{SiC}$ は, プラズマ CVD法(12) (14), 光CVD 法 $^{(15)}$, 電子線蒸着法 ${ }^{(16)}$, スパッタリング法 ${ }^{(17) \sim(19)}$, イオン プレーティング法 ${ }^{(20)}$ 等により形成されている。

本研究では, 以上のような多結晶 $\mathrm{SiC}$ 薄膜の特徵に着目 し, 多結晶SiC薄膜を用いた各種電子デバイスへの応用の 目的から，薄膜の低温形成が出来るプラズマCVD法により 多結晶 $\mathrm{SiC}$ 薄膜を形成し, その電気的, 結晶学的特性評価 について研究を行った。ブラズマCVD法による多結晶 $\mathrm{SiC}$ 薄膜の形成においては，その原料ガスとしてシラン $\left(\mathrm{SiH}_{4}\right)$
とメタン $\left(\mathrm{CH}_{4}\right)$ が一般的に用いられているが，SiH4 の持つ爆発性および毒性のため，法的にその取り扱いが規 制されており，取り扱いのためには大きな設備が必要とさ れている。そこで本研究では， $\mathrm{SiH}_{4} よ り$ 取り扱いが容易で 安全性が高い，四塩化ケイ素 $\left(\mathrm{SiCl}_{4}\right)$ を用いてプラズマCVD 法により初めて多結晶SiC薄膜を形成し，その電気的，結 晶学的特性評価について研究を行った。また, 多結晶 SiC 薄膜を，七ンサ等へ応用する場合に重要な特性のひとつで ある熱起電力の測定を行った。

\section{2 潯膜の形成方法}

多結晶 $\mathrm{SiC}$ 薄膜の形成に用いた平行平板形容量結合形プ ラズマCVD装置の概略図を図 1 に示す。高周波電源 $(13.56 \mathrm{MHz})$ は, 直径 $90 \mathrm{~mm} の$ 上部電極に印加した。上部電 極は，ステンレス鋼製で，復数個のガス導出孔があり，原 料ガスを吹き出す構造となっている。原料ガスとして，水 素 $\left(\mathrm{H}_{2}\right)$ 希釈の $1 \%$ の $\mathrm{SiCl}_{4}$ およひび $10 \%$ の $\mathrm{CH}_{4}$ を用いた。基板加 熱は，グラファイトヒータにより行い，基板電極間隔は， 約 $20 \mathrm{~mm}$ とした。高周波電力は, 同じ装置を用いた $\mathrm{SiH}_{4}-\mathrm{CH}_{4}$ 系で多結晶 $\mathrm{SiC}$ 薄膜を形成したときに, 70Wが最 適であったので，70Wとした。表1にプラズマCVD法によ る $\mathrm{SiC}$ 薄膜の形成条件を示す。

多秸晶 $\mathrm{SiC}$ 薄膜は, 反応容器内をまず $1 \times 10^{-3} \mathrm{~Pa}$ まで排気し 


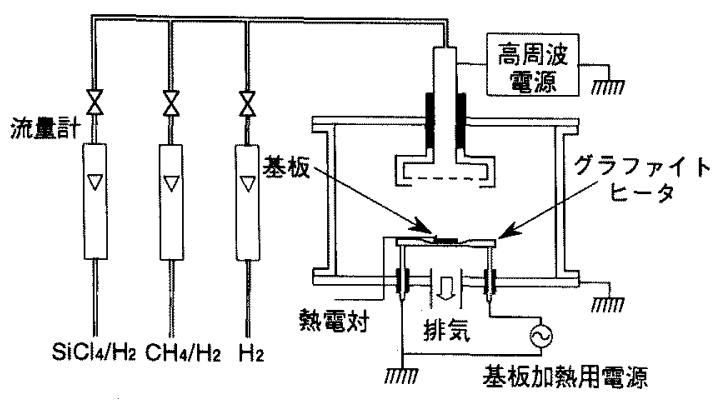

図 1 プラズマCVD装置の概略図

Fig.1. Schematic diagram of plasmaCVD equipment.

\section{表 1 薄膜の形成条件}

Table 1. Preparing conditions for film deposition.

\begin{tabular}{|c|c|c|}
\hline \multicolumn{2}{|c|}{ 反応ガス励起方式 } & 容量結合型 \\
\hline \multicolumn{2}{|c|}{ 基板温度 } & $700,750,800^{\circ} \mathrm{C}$ \\
\hline \multicolumn{2}{|c|}{ 高周波電力 [13.56MHz] } & $70 \mathrm{~W}$ \\
\hline \multicolumn{2}{|c|}{ 電力密度 } & $1.1 \mathrm{~W} / \mathrm{cm}^{2}$ \\
\hline \multicolumn{2}{|l|}{ 原料ガス } & $\begin{array}{l}1 \% \mathrm{SiCl}_{4} / \mathrm{H}_{2} \\
10 \% \mathrm{CH}_{4} / \mathrm{H}_{2}\end{array}$ \\
\hline 原料ガス流量 & $\begin{array}{l}\mathrm{SiCl}_{4} / \mathrm{H}_{2} \\
\mathrm{CH}_{4} / \mathrm{H}_{2}\end{array}$ & $\begin{array}{l}30 \mathrm{sccm} \\
5,15,30 \mathrm{sccm}\end{array}$ \\
\hline $\begin{array}{l}\text { 反応压力 } \\
\text { 基板材料 }\end{array}$ & & $\begin{array}{l}\text { 約 } 50 \mathrm{~Pa} \\
\text { バイコールガラス }\end{array}$ \\
\hline
\end{tabular}

た後， $\mathrm{H}_{2}$ を反応室内に導入して反応圧力にし，基板加熱お よび予備放電を行った。所定の基板温度になった後， $\mathrm{H}_{2}$ の 導入を止め, 原料ガスを導入し, 反応圧力約 $50 \mathrm{~Pa}$, 高周波 電力 70Wで薄膜の形成を行った。 $\mathrm{SiCl}_{4} / \mathrm{H}_{2}$ 流量は, $30 \mathrm{sccm}$ 一定とし， $\mathrm{CH}_{4} / \mathrm{H}_{2}$ 流量を $5 ， 15 ， 30 \mathrm{sccm}$ と変化させた。薄 膜の生成速度は， $\mathrm{CH}_{4} / \mathrm{H}_{2}$ 流量が $5,15 ， 30 \mathrm{sccm}$ の時，それ ぞれ約 $6,2 ， 1 \mathrm{~nm} / \mathrm{min}$ であった。

\section{$3 \mathrm{SiC}$ 薄膜の特性}

<3.1> 組成 $\quad \mathrm{SiCl}_{4} / \mathrm{H}_{2}$ 流量は $30 \mathrm{sccm}$ 一定とし， $\mathrm{CH}_{4} / \mathrm{H}_{2}$ 流量を $5 ， 15 ， 30 \mathrm{sccm}$ と変化させ，基板温度 700 , $750,800^{\circ} \mathrm{C}$ で形成した薄膜の炭素とシリコンの組成比を, XPS（島津ESCA-1000)により求めた結果を図 2 -(a)に示す。 $\mathrm{CH}_{4} / \mathrm{H}_{2}$ 流量が $5 \mathrm{sccm}$ の場合の薄膜の組成は，どの基板温度 の場合もほほ化学量論比になっているが，それより流量を 増やすと，炭素過剩な薄膜となっている。また，基板温度 が高いほど，同じ $\mathrm{CH}_{4} / \mathrm{H}_{2}$ 流量で形成した薄膜でも，上り炭 素過剩な薄膜となっている。これは， $\mathrm{CH}_{4}$ の分解がプラズ マだけではなく，温度にもよって行かれているためと考え られる。また，図 2 -(a)に示した薄膜には，塩素は含まれ ないが，数\%の酸素の存在がみとめられた。

組成比の反応圧力による変化を求めるため $\mathrm{SiCl}_{4} / \mathrm{H}_{2}$ と $\mathrm{CH}_{4} / \mathrm{H}_{2}$ 流量比を一定(6:1)にして, 総流量を変化させて, 反 応圧力を約 30 90Paまで変化させた時の炭素とシリコンの

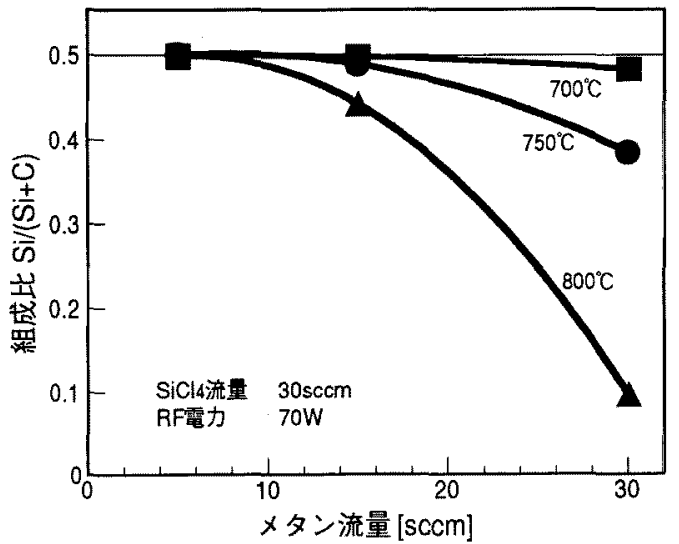

(a) 基板温度及びメタン流量による変化

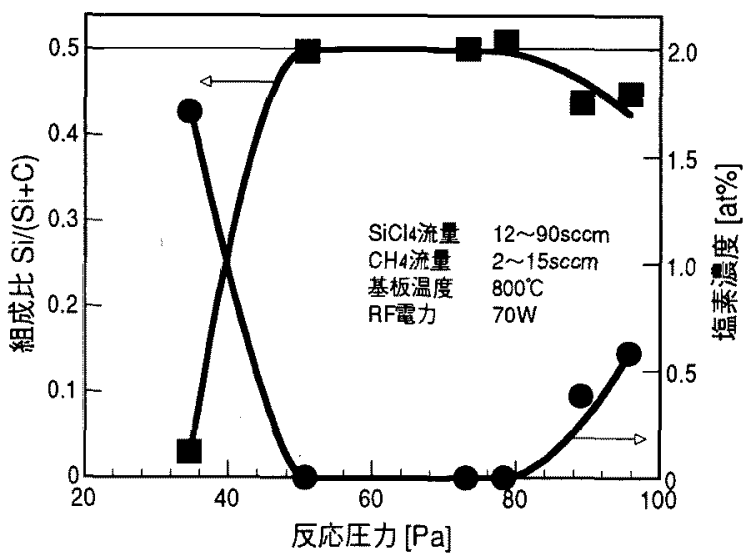

(b) 反応圧力による租成比と塩素濃度の変化

図 2 薄膜の組成

Fig.2. Composition ratio of thin films.

組成比, 薄膜中の塩素の割合を図 2 -(b)に示す。反応圧力 が50〜80Paの範囲では，ほほ化学量論比になっている薄膜 が形成されているが, それより, 反応圧力が低いときと高 いときでは，炭素過剩な薄膜で塩素を含んだ薄膜が得られ ている。これは, 反応圧力が低い場合は，プラズマの密度 が十分でなく $\mathrm{SiCl}_{4}$ が十分に分解されないため，反応圧力が 高い場合は分解できる量以上に 考えられる。

<3.2>結晶性 $\mathrm{SiCl}_{4} / \mathrm{H}_{2}$ 流量は30 $\mathrm{sccm}$ 一定とし, 基 板温度 $700,750,800^{\circ} \mathrm{C}$ で形成した薄膜のX線回折パターン (マックサイエンス $\mathrm{MXP}^{3}$ )を図 3 に示す。 $\mathrm{CH}_{4} / \mathrm{H}_{2}$ 流量は，基 板温度 $800^{\circ} \mathrm{C}$ で形成した薄膜は $5 \mathrm{sccm}$, 基板温度 700 及び $750^{\circ} \mathrm{C}$ で形成した薄膜は $15 \mathrm{sccm}$ で，それぞれの基板温度で $\mathrm{CH}_{4} / \mathrm{H}_{2}$ 流量を変化させて最も大きな回折パターンを示した ものである。それぞれの薄膜とも，3C-SiCの(111)面に帰属 すると考えられる $2 \theta=35.6^{\circ}$ のピークが観察され，多結晶 $\mathrm{SiC}$ 薄膜が形成されている。ピークの半值幅より求めた平均結 


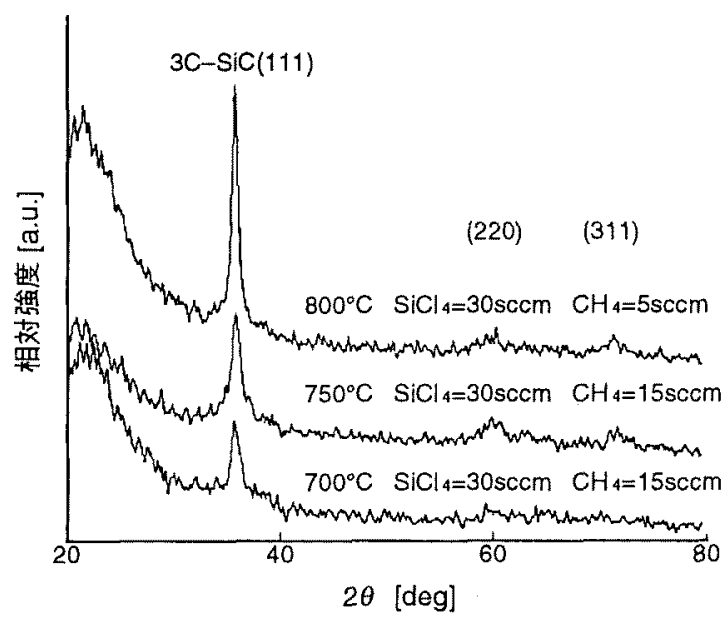

図 $3 \mathrm{SiC}$ 薄膜のX線回折パターン

Fig.3. Typical X-ray diffraction patterns of SiC films.

晶粒径は，基板温度が $700 ， 750 ， 800^{\circ} \mathrm{C}$ で，それぞれ䄪 $10 ， 15 ， 20 \mathrm{~nm}$ であった。基板温度 700 及び $750^{\circ} \mathrm{C} て ゙ は ，$ $\mathrm{CH}_{4} / \mathrm{H}_{2}$ 流量が5sccmk扮いて 为 3C-SiCの(111)面に帰属する と考えられるピークが観察されたが，15socmに比べてブロー ドなピークであった。また， $\mathrm{CH}_{4} / \mathrm{H}_{2}$ 流量が $30 \mathrm{sccm}$ では，ど の基板温度の場合もピークは観察されなかった。

以上の結果より，結晶粒径の大きな多結晶 $\mathrm{SiC}$ 薄膜の形 成には，分解されたシリコンに对して， $\mathrm{CH}_{4}$ より分解され て供粭される炭素がある程度の量が必要であると考えれれ る。つまり，熱により分解される $\mathrm{CH}_{4} / \mathrm{H}_{2}$ が少ない基板温度 700 及び $750^{\circ} \mathrm{C} て ゙$ 形成した薄膜では， $\mathrm{CH}_{4} / \mathrm{H}_{2}$ 流量が多い $15 \mathrm{sccm}$ で結晶粒径の大きな薄膜が形成され，熱による $\mathrm{CH}_{4}$ の分解が多い基板温度 $800^{\circ} \mathrm{C}$ で形成した薄膜では， $\mathrm{CH}_{4} / \mathrm{H}_{2}$ 流量が $5 \mathrm{sccm}$ で結晶粒径の大きな薄膜が形成されている。

また，薄膜の組成比が化学量諭比より大きく外れた薄膜 では，多結晶 $\mathrm{SiC}$ 薄膜は形成されていない。このことは， 過剩の炭素が結晶粒の成長を抑制していると考えられる。

<3.3> 光学的特性 $\mathrm{SiCl}_{4} / \mathrm{H}_{2}$ 流量は $30 \mathrm{sccm}$ 一定とし， $\mathrm{CH}_{4} / \mathrm{H}_{2}$ 流量を $5 ， 15 ， 30 \mathrm{sccm}$ と変化させ，基板温度 700 ， $750,800^{\circ} \mathrm{C}$ で形成した薄膜の透過率から $(\alpha d h v)^{12}-h v$ プロッ 卜を行い，直線部分を外挿して $h v$ 軸を横切るエネルギー值 加ら求めた光学的エネルギーギャップを図 4 に示す。図 3 にX線回折結果を示した形成条件で形成した薄膜は，1.9〜 $2.2 \mathrm{eV}$ 值を示し，3C-SiCの光学的エネルギーギャップ $(2.2 \mathrm{eV})$ に近い値である。2.2eVからのず机は，薄膜中の過 剩な炭素及び，薄膜がアモルファスになっているためと考 えられる。

<3.4> 電気的特性 $\mathrm{SiCl}_{4} / \mathrm{H}_{2}$ 流量仙 $30 \mathrm{~s} \mathrm{ccm}$ 一定とし， $\mathrm{CH}_{4} / \mathrm{H}_{2}$ 流量を $5 ， 15 ， 30 \mathrm{sccm}$ と変化させ，基板温度 700 , $750 ， 800^{\circ} \mathrm{C}$ で形成した溥膜の，van der Pauw法により求め た抵抗率，キャリア濃度，ホール移動度を図 5 に示す。一 番大きな平均結晶粒径を示した， $\mathrm{CH}_{4} / \mathrm{H}_{2}$ 流量 $5 \mathrm{sccm}$, 基板

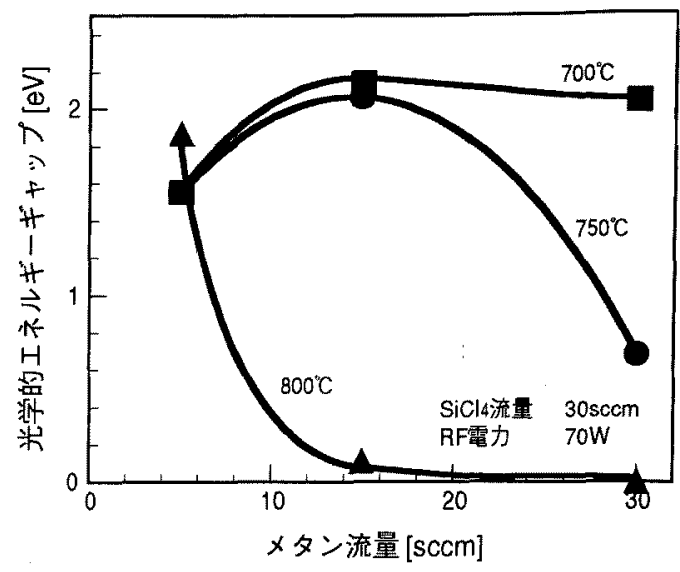

図 4 基板温度及びメタン流量による 光学的エネルギーギャップの変化

Fig.4. Dependence of optical energy gap on the substrate temperature and flow rate of $\mathrm{CH}_{4} / \mathrm{H}_{2}$.

温度 $800^{\circ} \mathrm{C}$ で形成した薄膜の抵抗率，キャリア濃度，ホー ル移動度はそれぞれ，約 $3 \Omega \cdot \mathrm{cm}, 2 \times 10^{17} \mathrm{~cm}^{-3}, 20 \mathrm{~cm}^{2} / \mathrm{V} \cdot \mathrm{sec}$ あった。これらの值は，抵抗率が1桁大きいが， $\mathrm{SiH}_{4}$ と $\mathrm{CH}_{4}$ を用いたプラズマCVD法による多結晶 $\mathrm{SiC}$ 薄膜と同程度 の值である。

$\mathrm{CH}_{4} / \mathrm{H}_{2}$ 流量が $5 \mathrm{sccm}$ で形成した薄膜と $15 \mathrm{sccm}$ 以上で形成 した薄膜では，基板温度に対する抵抗率，キャリア濃度の 変化が逆転している。 $\mathrm{CH}_{4} / \mathrm{H}_{2}$ 流量が $5 \mathrm{sccm}$ の場合は, 基板 温度が上昇するほど抵抗率は大きくなりキャリア濃度は小 さくなっているが，15sccm以上では，基板温度が上昇する ほど抵抗率は小さくなりキャリア濃度は大きくなっている。 ホール移動度は基板温度が大きいほど，大きな値を示して いる。

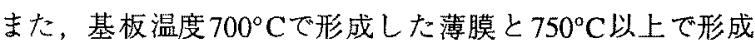
した薄膜では， $\mathrm{CH}_{4} / \mathrm{H}_{2}$ 流量に対する抵抗率，キャリア濃度 の変化が逆転している。基板温度が $700^{\circ} \mathrm{C}$ 場合は, $\mathrm{CH}_{4} / \mathrm{H}_{2}$ 流量が大きくなるほど抵抗率は大きくなりキャリア 濃度は小さくなっているが, $750^{\circ} \mathrm{C}$ 以上では， $\mathrm{CH}_{4} / \mathrm{H}_{2}$ 流量 が大きくなるほど抵抗率は小さくなりキャリア濃度は大き くなっている。

以上のことは，薄膜に供給される炭素がプラズマによっ て分解されたものが多いのか，熱によって分解されたもの が多いのかによって，SiC薄膜形成のメカニズムが影響を 受け，電気的特性の変化に現れていると考えられる。

薄膜の伝導の型は, どの基板温度で形成した場合におい ても, $\mathrm{CH}_{4} / \mathrm{H}_{2}$ 流量が $5 \mathrm{sccm}$ の場合は, $\mathrm{n}$ 型を示し, $15 \mathrm{sccm}$ 以 上では，p型を示した。このことは，薄膜中に含まれる元 素で $\mathrm{CH}_{4} / \mathrm{H}_{2}$ 流量により変化するのは炭素だけであるので, $\mathrm{SiCl}_{4}$ とCH4 原料ガスに用いたプラズマ CVD法による SiC 薄膜では，薄膜中の過剩な炭素の一部がアクセプタの準位 に入ってp型の電気伝導を示していると考えられる。つま り, 膜中の炭素濃度を制御することにより, 電気伝導の型 


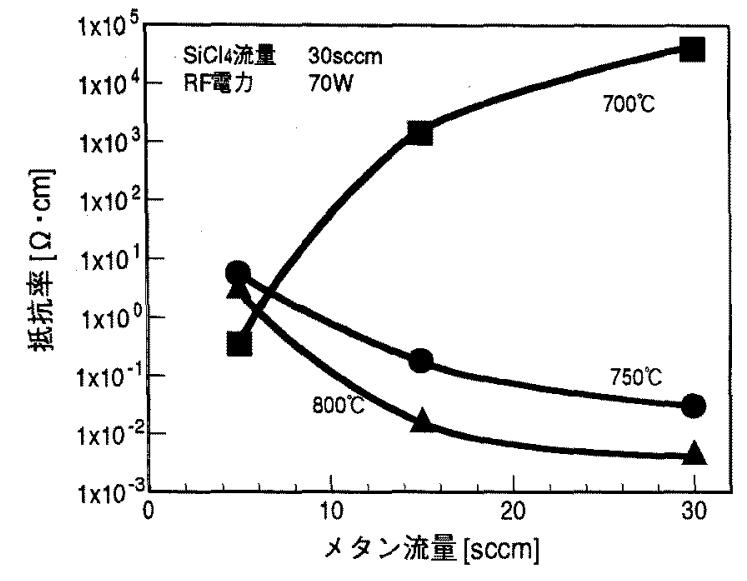

(a) 抵抗率

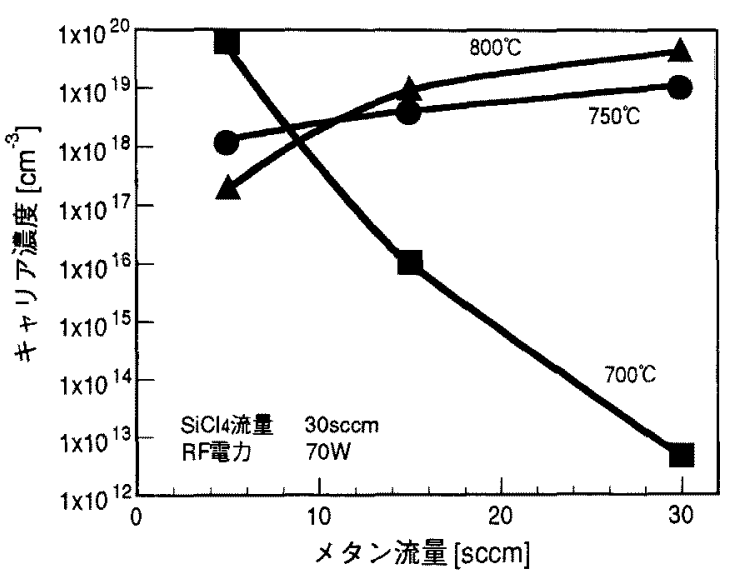

(b) キャリア濃度

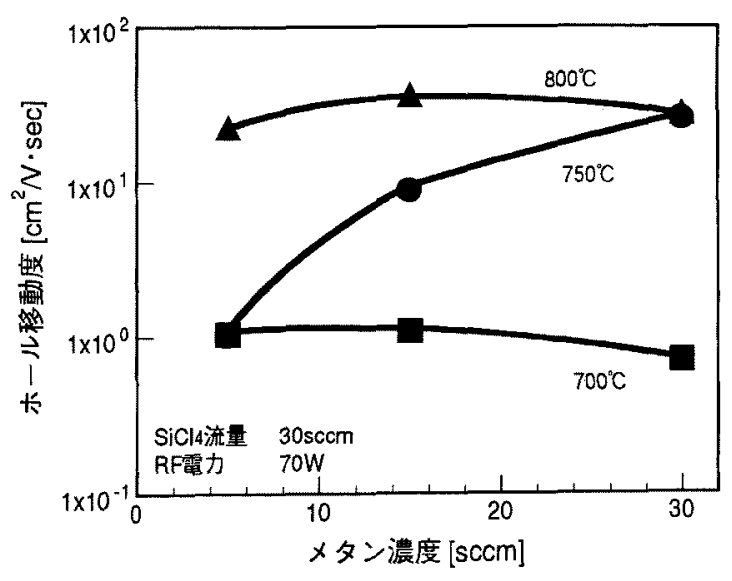

(c) ホール移動度

図 5 基板温度及びメタン流量による抵抗率, キャリア濃度、ホール移動度の変化

Fig.5. Dependence of resistivity, carrier concentration and hall mobility on the substrate temperature and flow rate of $\mathrm{CH}_{4} / \mathrm{H}_{2}$.

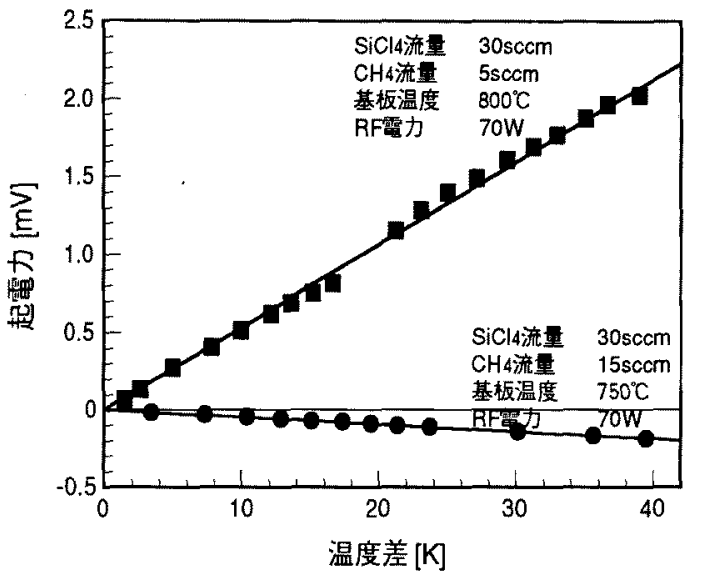

図 $6 \mathrm{SiC}$ 薄膜の熱起電力

Fig.6. Thermoelectromotive force of $\mathrm{SiC}$ thin films.

を制御できる可能性があることを示している。

く3.5> 熱起電力 $\quad \mathrm{SiC}$ 薄膜のセンサへの応用のための 特性のひとつである熱起電力を測定した。基板温度 $800^{\circ} \mathrm{C}, \mathrm{CH}_{4} / \mathrm{H}_{2}$ 流量 $5 \mathrm{sccm}$ 及び, 基板温度 $750^{\circ} \mathrm{C}, \mathrm{CH}_{4} / \mathrm{H}_{2}$ 流 量 $15 \mathrm{sccm}$ で形成した薄膜の熱起電力の, オーミック電極

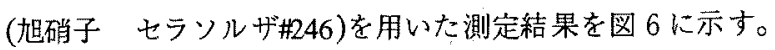

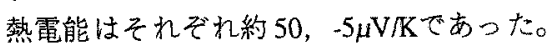

4 まとめ

$\mathrm{SiCl}_{4}$ とCH 4 を原料ガスに用いたプラズマCVD法により多 結晶 $\mathrm{SiC}$ 薄膜を形成し，その結晶学的及び電気的特性の評 価を行った。その結果，以下のことが明らかになった。

(1) 基板温度 $700^{\circ} \mathrm{C}$ 以上で, 平均結晶粒径 $10 \sim 20 \mathrm{~nm}$ の多 結晶 $\mathrm{SiC}$ 薄膜が形成できた。

(2) 形成した多結晶 $\mathrm{SiC}$ 薄膜の光学的エネルギーギャッ

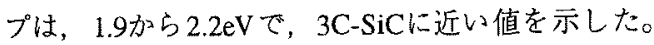

(3) $\mathrm{SiCl}_{4} / \mathrm{H}_{2}$ 流量は $30 \mathrm{secm}, \mathrm{CH}_{4} / \mathrm{H}_{2}$ 流量 $5 \mathrm{sccm}$ ，基板温度 $800^{\circ} \mathrm{C}$ で形成した多結晶 $\mathrm{SiC}$ 薄膜は結晶性が良く，その抵抗 率, キャリア濃度，ホール移動度はそれぞれ，約 $3 \Omega \cdot \mathrm{cm}$, $2 \times 10^{17} \mathrm{~cm}^{-3}, 20 \mathrm{~cm}^{2} / \mathrm{V} \cdot \mathrm{sec}$ であった。

(4) 形成した多秸晶 $\mathrm{SiC}$ 薄膜は, 薄膜中の炭素濃度を制 御することにより，導電の型を $\mathrm{n}$ 型から $\mathrm{p}$ 型へ制御できる可 能性がある。

(5) $\mathrm{SiCl}_{4} / \mathrm{H}_{2}$ 流量は $30 \mathrm{sccm}, \mathrm{CH}_{4} / \mathrm{H}_{2}$ 流量 $5 \mathrm{sccm}$, 基板温度 $800^{\circ} \mathrm{C}$ で形成した多結晶 $\mathrm{SiC}$ 薄膜の熱電能は, 約 $50 \mu \mathrm{V} / \mathrm{K}$ であっ た。

以上の結果から，本研究で得られた多結晶 $\mathrm{SiC}$ 薄膜は， $\mathrm{SiH}_{4}$ を用いた多結晶 $\mathrm{SiC}$ 薄膜と同程度の電気的特性を示す ので, 高温度環境におけるセンサ素子，へテロ接合デバイ ス等への応用が期待される。

本研究の一部は，文部省科学研究費補助金の援助を受け て行われた。

(平成 6 年 9 月 19 日受付, 同 7 年 1 月 10 日再受付) 


\section{文献}

(1) K. Wasa, T. Tohda, Y. Kasahara and S. Hayakawa: "Highly reliable temperature sensor using rf-sputtered $\mathrm{SiC}$ thin film", Rev. Sci. Instrum., 50, 1084-1088 (1979-9)

(2) G. Ziegler, P. Lanig, D. Theis and C. Weyrich: "Single Crystal Growth of SiC Substrate Material for Blue Light Emitting Diodes", IEEE Trans. ED., ED-30, 277-281(1983-4)

(3) T. Sugii, T. Ito, Y. Furumura, M. Doki, F. Mieno and M. Maeda: "Si Heterojunction Bipolar Transistors with SingleCrystalline $\beta$-SiC Emitters", J. Electrochem. Soc., 134, 25452549(1987-10)

(4) T. Sugii, T. Aoyama and T. Ito: "Polycrystalline SiC for a Wide-Bandgap Emitter of Si-HBTs", J. Electrochem. Soc., 136, 3111-3115(1989-10)

(5) Y. Onuma, K. Kamimura, Y. Nagura, H. Cai and M. Kiuchi: "Polycrystalline Silicon Carbide Films for Piezoresistive Elements", Sens. and Materials 2, 207-216(1991)

(6) A. Solangi and M. I. Chaudhry: "Fabrication and Electrical Properties of $\beta-\mathrm{SiC} / \mathrm{Si}$ and Poly-SiC/Si Solar Cells", Springer Proc. in Phys. (ACSCIV), 71, 362-367(1992)

(7) S. Minagwa and H. C. Gatos: "Epitaxial Growth of $\alpha$-SiC from the Vapor Phase", Jpn. J.Appl.Phys., 10, 1680-1690(197112)

(8) H. Matsunami, S. Nishino and T. Tanaka: "HETEROEPITAXIAL GROWTH OF $\beta$-SiC ON SILICON SUBSTRATE USING $\mathrm{SiCl}_{4}-\mathrm{C}_{3} \mathrm{H}_{8}-\mathrm{H}_{2}$ SYSTEM", J. Cryst. Growth, 45, 138143(1978)

（9）古村雄二 ·土岐雅彦 ·三重野文健 - 前田守：「 $\mathrm{SiHCl}_{3-}$ $\mathrm{C}_{3} \mathrm{H}_{8}-\mathrm{H}_{2}$ 系から成長させた $\beta-\mathrm{SiC}$ 膜の特性」, 電通学論 $\mathrm{C}$, J69-C, 705-714(昭61-6)

(10)M. I. Chaudhry and R. L.Wright: "Epitaxial growth of $\beta-S i C$ on $\mathrm{Si}$ by low-temperature chemical vapor deposition", $J$. Mater. Res., 5, 1595-1598(1990-8)

(11)T.Yoshinobu, H. Mitsui, Y. Tarui, T.Fuyuki and H. Matsunami: "Heteroepitaxial growth of single crystalline $3 \mathrm{C}-\mathrm{SiC}$ on $\mathrm{Si}$ substrates by gas source molecular beam epitaxy", J. Appl. Phys., 72, 2006-2013(1992-9)

(12)A. Chayahara, A. Masuda, T. Imura and Y. Osaka: "Formation of Polycrystalline SiC in ESR Plasma", Jpn. J. Appl. Phys., 25, L564-L566(1986-7)

(13)小沼義治 ·上村喜一 - 長畦文男 - 関広之 - 手塚恭一 : 「プラズマ CVD法による多結晶 $\mathrm{SiC}$ 薄膜」, 電学論 $\mathrm{A}$, 109, 219-226(平1-5)

(14)G. Ganguly, S. C. De, S. Ray and K. Barua: "Polycrystalline silicon carbide films deposited by low-power radio-frequency plasma decomposition of $\mathrm{SiF}_{4}-\mathrm{CF}_{4}-\mathrm{H}_{2}$ gas mixtures", J. Appl. Phys., 69, 3915-3923(1991-4)

(15)T.Noda, H. Suzuki, H. Araki, F. Abe and M. Okada: "Formation of polycrystalline $\mathrm{SiC}$ film by excimer-laser chemical vapour deposition", J. Mater. Sci. Letters, 11, 477-148(1992)
(16) Y. Onuma: "Silicon Carbide Films Evaporated in Vacuum on Synthetic Micas", Jpn. J. Appl. Phys., 8, 401(1969)

(17)K. Wasa, T. Nagai and S. Hayakawa: "STRUCTURE AND MECHANICAL PROPERTIES OF R.F. SPUTTERED SiC FLLMS", Thin Solid Films, 31, 235-241(1976)

(18)T. Tohda, K. Wasa and S. Hayakawa: "Effects of Target Materials on the Structural Properties of Sputtered SiC Films", J. Electrochem. Soc., 127, 44-47(1980-1)

(19)中村祐一 - 笹川悟 ·上村喜一 - 中尾真人 - 小沼義治 · 米久保荘：「スパッタリング法による $\mathrm{SiC}$ 薄膜の生成」 信学技報, SDM93-159, 43-48(1993-12)

(20) Y. Murayama and T. Takao: "STRUCTURE OF A SILICON CARBIDE FILM SYNTHESIZED BY R.F. REACTIVE ION PLATING", Thin Solid Films, 40, 309-317(1977)

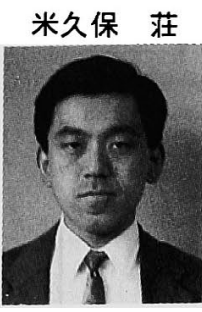

（正員）1959年6月 18日生まれ。82年3月信 州大学理学部物理学科卒業。86年4月長野 県精密工業試験場入所。92年 4 月信州大学 大学院工学系研究科博士後期課程社会人特 別選抜入学。現在, 同3年在学中。応用物 理学会, 日本物理学会, 電子情報通信学会, 日本表面科学会, 日本材料科学会会員。

田中 裕之 (非会員) 1969年12月22日生まれ。92年3 月信州大学工学部電気工学科卒業。94年3 2 月同大学大学院工学系研究科電気電子工学 専攻博士前期課程修了。同年 4 月富士電機 (侏)入社。

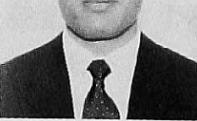

上村 喜一（正員）1950年2月20日生まれ。72年3月新

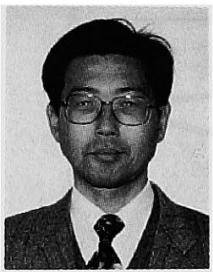
潟大学工学部電子工学科卒業。77年3月東 京工業大学大学院博士課程修了。同年4月 東京工芸大学工学部講師。83年4月信州大 学工学部助教授。工学博士。応用物理学会, 電子情報通信学会, IEEE, MRS会員。

小沼 義治 （正員）1937年1月25日生まれ。59年3月信 州大学工学部電気工学科卒業。同年 4 月同
大学工学部助手。82年 4 月同教授。工学博
士。応用物理学会, 電子情報通信学会, 日
本表面科学会, 日本材料科学会, 日本セラ
ミックス協会, IEEE, MRS会員。 